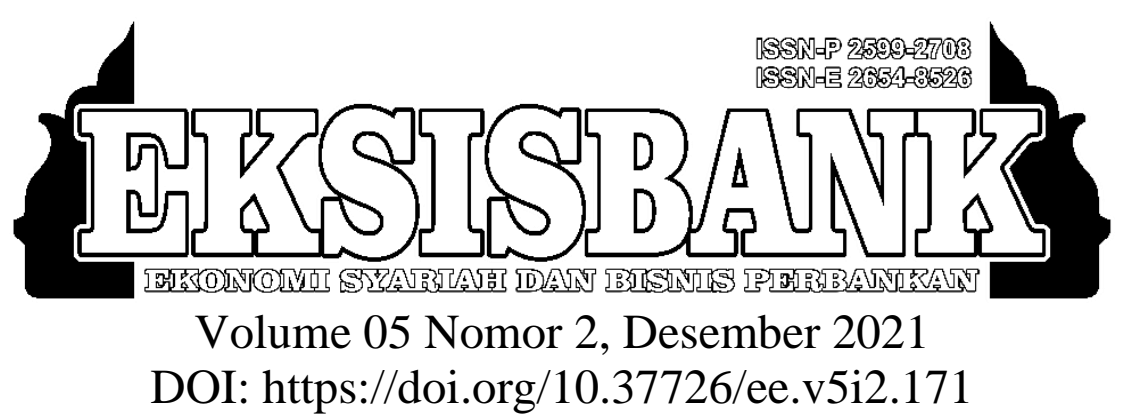

\title{
Analisis Kinerja Keuangan Bank Syariah Dengan Metode DuPont System Pada PT. Bank BRI Syariah Periode 2016-2019
}

\author{
Dewi Nurapiah $^{1}$, Moch. Cahyo Sucipto ${ }^{2}$, Eka Ahadiyat Suryana ${ }^{3}$ \\ ${ }^{1,2,3}$ Sekolah Tinggi Iilmu Ekonomi Syariah (STIES) Indonesia Purwakarta \\ Jalan Veteran No. 150-152 Ciseureuh Purwakarta 41118 Jawa Barat Indonesia \\ 1nurapiahdewi@gmail.com \\ ${ }^{2}$ cahyosucipto@sties-purwakarta.ac.id \\ 3ekaahadi@sties-purwakarta.ac.id
}

\begin{abstract}
ABSTRAK
Pengukuran kinerja keuangan sangat penting dilakukan dengan cara menggali lebih banyak informasi yang terkandung dalam laporan keuangan, laporan keuangan merupakan hasil akhir dari proses akuntansi, dimana harus memberikan informasi yang berguna untuk pengambilan keputusan berbagai pihak. Penelitian ini bertujuan untuk memperoleh gambaran tentang kinerja keuangan perusahaan dengan penerapan metode DuPont System. Disamping itu dengan analisis ini dapat mengevaluasi perubahan-perubahan kondisi dan kinerja perusahaan, apakah ada peningkatan atau penurunan atau kedua-duanya. Variabel yang digunakan dalam perhitungan DuPont System yaitu Return On Investment, Total Asset Turnover, dan Net Profit Margin. Metode yang digunakan pada penelitian ini adalah Deskriptif kuantitatif, Sumber data yang di perlukan dalam penelitian ini yaitu data sekunder, data yang di pergunakan dalam penelitian ini adalah data-data yang dipublikasikan oleh Bank BRI Syariah dan laporan publikasi Bank BRI Syariah yang ada pada Otoritas Jasa Keuangan (OJK). Hasil penelitian ini menunjukkan bahwa kinerja BRISyariah mengalami fluktuatif tiap tahunnya. Dimana cenderung menurun pada tingkat Net Profit Margin, Total Assets Turnover, dan Return On Investment. Net Profit Margin tertinggi selama lima tahun terjadi pada tahun 2016 sebesar 6,16\% dan paling rendah terjadi pada tahun 2019 sebesar 2,04\%. Total Assets Turnover terbesar yaitu 0,10 kali pada tahun 2016 dan paling rendah sebesar 0.08 kali pada tahun 2019. Return On Invesmen paling tinggi sebesar 0,16\% pada tahun 2016 dan paling rendah psebesar 0,17\% pada tahun 2019. Hal ini menunjukan bahwa kinerja Bank BRI Syariah dalam menghasilkan laba dikatakan kurang baik karena cenderung mengalami penurunan setiap tahunya, meski tingkat DuPont System pada Bank BRI Syariah mengalami fluktuasi, namun
\end{abstract}


masih dikatakan positif dikarenakan pada penetapan kriteria tingkat DuPont Syatem yaitu ROI Bank BRI Syariah masih dikatakan cukup sehat.

Kata kunci- Kinerja Keuangan, DuPont System, Net Profit Margin, Total Assets Turnover, Return On Investment..

\section{ABSTRACT}

It is very important to measure financial performance by digging up more information contained in financial statements, financial statements are the end result of the accounting process, which must provide useful information for decision making by various parties. This study aims to obtain an overview of the company's financial performance by applying the DuPont System method. In addition, this analysis can evaluate changes in company conditions and performance, whether there is an increase or decrease or both. The variables used in the DuPont System calculation are Return On Investment, Total Asset Turnover, and Net Profit Margin. The method used in this study is quantitative descriptive, the source of the data needed in this study is secondary data, the data used in this study are data published by BRI Syariah Bank and BRI Syariah Bank publication reports that exist at the Service Authority. Finance (OJK). The results of this study indicate that the performance of BRISyariah fluctuates every year. Where tends to decrease at the level of Net Profit Margin, Total Assets Turnover, and Return On Investment. The highest Net Profit Margin for five years occurred in 2016 at $6.16 \%$ and the lowest occurred in 2019 at 2.04\%. The largest Total Assets Turnover was 0.10 times in 2016 and the lowest was 0.08 times in 2019. The highest Return On Investment was $0.16 \%$ in 2016 and the lowest was $0.17 \%$ in 2019. This shows that the performance of BRI Syariah Bank in generating profits is said to be poor because it tends to decrease every year, even though the level of the DuPont System at BRI Syariah Banks has fluctuated, but it is still said to be positive due to the determination of the DuPont Syatem level criteria, namely the ROI of BRI Syariah Banks is still quite healthy.

Keywords - Financial Performance, DuPont System, Net Profit Margin, Total Assets Turnover, Return On Investment.

\section{PENDAHULUAN}

Masyarakat luas mengukur keberhasilan perusahaan berdasarkan kemampuan perusahaan yang terlihat dari kinerja perusahaan dalam menghasilkan laba. Oleh karena itu suatu Bank seharusnya menjaga kepercayaan masyarakat dengan meningkatkan kinerja keuangan. Baik atau burknya suatu kinerja keuangan bank merupakan cerminan kemampuan perbankan dalam mengelola dan mengalokasi sumber dayanya. Oleh karena itu, penting bagi bank untuk mengukur kinerja keuangannya. Kinerja keuangan merupakan suatu analisis yang di lakukan untuk melihat sejauh mana perusahaan telah melaksanakan dengan menggunakan aturan-aturan pelaksanaan keuangan secara baik dan benar (Kariyoto 2017).

Pengukuran kinerja keuangan sangat penting sebagai saran dalam rangka memperbaiki kegiatan operasional perusahaan dengan perbaikan kinerja operasional diharapkan bahwa perusahaan dapat mengalami pertumbuhan keuangan yang lebih baik dan juga dapat bersaing dengan perusahaan lain. Pengukuran kinerja keuangan dapat dilakukan dengan menganalisis laporan keuangannya. Menganalisis laporan keuangan berarti menggali lebih banyak informasi yang terkandung dalam suatu laporan keuangan.

EKSISBANK (Ekonomi Syariah dan Bisnis Perbankan), Volume 5, Nomor 2, Desember 2021 
Laporan keuangan merupakan hasil akhir dari proses akuntansi. Sebagai hasil akhir dari proses akuntansi laporan keuangan memberikan informasi yang berguna untuk pengambilan keputusan berbagai pihak (Suwiknyo 2019).

Menurut Munawir, laporan merupaka salah satu informasi keuangan yang bersumber dari intern perusahaan yang bersangkutan. Pihakpihak yang menginvestasikan modalnya membutuhkan informasi tentang sejauh mana kelancaran aktivitas dan profitabilitas perusahaan, potensi deviden, karena dengan informasi tersebut pemegang saham dapat memutuskan untuk mempertahankan sahamnya, menjual, atau bahkan menambahnya (Munawir 2016).

Metode yang bisa digunakan untuk mengukur kinerja keuangan, antara lain : Analisis Rasio, Analisis Nilai Tambah Pasar (Market Value Added/ MVA), Analisis Nilai Tambah Ekonomis (Economic Value Aded/ EVA) dan Blance Score Card (BSC), Analisis Capital Asset, Management, Equity, and Liquidity (CAMEL) (Warsono 2016). Selain metode tersebut ada sebuah metode yang lebih sederhana, integratif, dan menggambarkan keseluruhan kinerja keuangan, yaitu metode DuPont System. DuPont Syatem merupakan suatu metode yang digunakan untuk menilai efektivitas operasional perusahaan, karena dalam analisis ini mencakup unsur penjualan, dan aktiva yang digunakan setra laba yang dihasilakan perusahaan.(Wilmar Amonio Gulo 2011) DuPont System dapat membantu analis untuk mengetahui hubungan antara Return On Invesment (ROI), Total Assets Turn over (TATO), dan Net Profit Margin (NPM). Dengan menggunakan Return On Invesment (ROI) dapat mengevaluasi perubahan-perubahan kondisi dan kinerja perusahaan, apakah ada perbaikan atau pemburukan atau malah kedua-duanya (Lemiyana 2015).
Berdasarkan data dari laporan keuangan Bank BRI Syariah bahwa selalu menunjukan usahanya yang maksimal untuk meningkatkan kinerjanya. Hal ini dapat dilihat dari pertumbuhan aset Bank BRI Syariah dilihat pada tabel berikut :

Tabel 1

Pertumbuhan Aset Bank BRI Syariah 20162019

\begin{tabular}{|c|c|}
\hline Tahun & $\begin{array}{l}\text { Total Aset Bank BRI } \\
\text { Syariah }\end{array}$ \\
\hline 2016 & 27.687 .188 .000 .000 \\
\hline 2017 & 31.543 .384 .000 .000 \\
\hline 2018 & 37.869 .177 .000 .000 \\
\hline 2019 & 43.123 .488 .000 .000 \\
\hline
\end{tabular}

Sumber : Annual Report Bank Bri Syariah

Berdasarkan data tabel di atas pertumbuhan aset Bank BRI Syariah pada tahun 2016 tercatat sebesar Rp27,69 triliun, dan mengalami pertumbuhan aset sebesar $13.49 \%$ menjadi 31,54 triliun, Bank juga berhasil mencatatkan pertumbuhan aset sebesar Rp37,87 triliun pada tahun 2018 dari Rp31,54 triliun di tahun 2017, dan pada tahun 2019 aset Bank BRI Syariah tercatat sebesar 13,87\% menjadi 43,12 triliun dari 37,87 triliun di tahun 2018 (BRI Syariah 2020).

Tabel 2

Laba Bersih Bank BRI Syariah 2016-2019

\begin{tabular}{|c|c|}
\hline Tahun & $\begin{array}{c}\text { Laba Bersih Bank BNI } \\
\text { Syariah }\end{array}$ \\
\hline 2016 & 170.209 .000 .000 \\
\hline 2017 & 101.091 .000 .000 \\
\hline 2018 & 106.600 .000 .000 \\
\hline 2019 & 74.016 .000 .000 \\
\hline
\end{tabular}

Sumber : Annual Report Bank Bri Syariah

Laba bersih yang dibukukan BRI Syariah pada tahun 2017 adalah sebesar Rp101 miliar. Jumlah tersebut mengalami penurunan sebesar 40,61\% dibandingkan laba bersih tahun 2016 sebesar Rp170 miliar. Penurunan 
laba bersih tersebut salah satunya disebabkan oleh meningkatnya cadangan kerugian yang dialokasikan Bank untuk menekan risiko pada masa yang akan datang. Laba bersih di tahun 2018 sebesar Rp 106,6 miliar, meningkat 5,45\% dari laba bersih di tahun 2017 sebesar Rp 101 miliar. Dan pada tahun 2019 laba bersih bank BRI Syariah meurun 31\% sebesar Rp.74,016 miliar dari tahun sebelumnya 106,6 miliar (BRI Syariah 2020).

Berdasatkan uraian di atas peneliti tertarik untuk melakukan penelitian dengan metode Analisis Kinerja Keuangan Dengan Menggunakan Metode DuPont System pada Bank Syariah di Indonesia yaitu pada Bank BRI Syariah, untuk mengetahui perkembangan kondisi keuangan pada Bank Syariah di Indonesia apakah mengalami kenaikan atau penurunan dalam kinerja keuangan. Apa bila satu Bank Syariah sudah terindikasi menuju penurunan kinerja keuangan maka manajemen bisa segera melakukan perbaikan-perbaikan agar perusahaan tidak mengalami kebangkrutan. Di samping itu, bagi pihak eksternal perusahaan, prediksi kondisi keuangan ini bisa di gunakan sebagai landasan dalam pengambilan keputusan financial. Penelitian ini bertujuan untuk memperoleh gambaran tentang kinerja keuangan perusahaan dengan penerapan metode DuPont System. Berdasarkan latar belakang inilah membuat peneliti tertarik untuk melakukan penelitian dengan judul: "Analisis Kinerja Keuangan Bank Syariah Dengan Metode DuPont System Pada PT. Bank BRI Syariah Periode 20162019".

Penelitian ini bertujuan untuk memperoleh gambaran tentang kinerja keuangan perusahaan dengan penerapan metode DuPont System. Disamping itu dengan analisis ini dapat mengevaluasi perubahan-perubahan kondisi dan kinerja perusahaan, apakah ada peningkatan atau penurunan atau kedua- duanya. Variabel yang digunakan dalam perhitungan DuPont System yaitu Return On Investment, Total Asset Turnover, dan Net Profit Margin.

\section{TINJAUAN PUSTAKA}

A. Landasan Teori

Definisi kinerja berdasarkan Kamus Besar Bahasa Indonesia (KBBI) adalah sesuatu yang dicapai, prestasi yang diperlihatkan atau kemampuan kerja. Untuk mengetahui pencapaian yang diperoleh berdasarkan pada target dan tujuan yang telah ditetapkan dari awal perlu untuk dilakukan pengukuran kinerja. Pengukuran kinerja ini adalah hal yang penting dalam sebuah organisasi atau perusahaan agar dapat meningkatkan kinerjanya. Sistem pengukuran kinerja yang tepat merupakan salah satu kunci kesuksesan perusahaan (Rahayu 2021).

Secara umum, kinerja (performance) memberikan suatu gambaran tentang keberhasilan atau kegagalan dari suatu organisasi atau perusahaan dalam melaksanakan tugasnya dalam rangka mencapai tujuan yang ditetapkan oleh organisasi atau perusahaan tersebut (Syamsul 2017).

Kinerja keuangan adalah suatu kajian yang dilakukan untuk memberikan gambaran sejauh mana suatu perusahaan telah melaksanakan usahanya dengan menggunakan aturan-aturan pelaksanaan keuangan secara baik dan benar (Syamsul 2017).

Menurut Sofyan Safri Harahap Du Pont sudah dikenal sebagai pengusaha yang sukses. Dalam bisnisnya ia memiliki cara sendiri dalam menganalisa laporan keuangan. Caranya sebenarnya sama dengan analisis laporan keuangan biasa, namun pendekatannya lebih integratif dan menggunakan komposisi laporan keuangan sebagai elemen analisisnya. Du Pont 
menganggap Return On Investment (ROI) sehingga ia memulai analisisnya dari angka ini (Harnita 2020).

Menurut lemiyana DuPont Syatem adalah suatu sistem analisis yang dimaksudkan untuk menunjukan hubungan antara return in invrsment (ROI), total assets turn over (TATO), Net Profit Margin (NPM), return on equity (ROE) adalah asio keutungan neto sesudah pajak dengan jumlah investasi sehinga dalam DuPont Syatem juga di perhitungkan juga bunga dan pajak. Metode DuPont System ini memberikan informasi mengenai berbagai faktor yang menyebabkan naik turunnya kinerja keuangan sebuah perusahaan, caranya sebenarnya hampir sama dengan analisis laporan keuangan biasa, namun pendekatannya lebih integrative dengan menoggunakan komposisi laporan keuangan sebagai elemen analisisnya, dan mengurangi pos-pos laporan keuangan sampai mendetail, yaitu dengan menganalisis rasio keuangan agar perusahaan dapat mengetahui berbagai faktor yang mempengaruhi efektivitasnya dalam mengelola sumber daya yang perusahaan miliki sehingga perencanaan keuangannya akan lebih baik dimasa yang akandatang (Butar 2019).

Adapun teknik analisis yang digunakan dalam penelitian ini adalah dengan menggunakan DuPont System, Dengan langkah-langkah berikut (Moridu 2020):

1. Menentukan Net Profit Margin (NPM)

$$
\mathrm{NPM}=\frac{\text { Laba bersih }}{\text { Pendapatan }} \times 100 \%
$$

\section{Menentukan Total Aset Turnover} (TATO)

$$
\text { TATO }=\frac{\text { Pendapatan }}{\text { Total Aktiva }} \times 1 \text { Kali }
$$

\section{Manenentukan Return On Invesment (ROI)}

\section{$\mathrm{ROI}=\quad N P M \times T A T O$}

\section{B. Penelitian Terdahulu}

Penelitian tentang kinerja keuangan dengan metode DuPont System, sudah banyak dilakukan penelitian oleh peneliti sebelumnya, seperti penelitian-penelitian sebagai berikut:

1.Penilaian Kinerja Keuangan lima Perusahaan Perbankan Terbesar Periode 2010-2012 menunggunakan DuPont System (Lesmana 2013).

Penilaian kinerja perusahaan dapat dilihat dari aspek keuangan dan non keuangan. Penelitian ini secara khusus mencoba mengukur kinerja keuangan dengan menggunakan analisis keuangan sistem DuPont. Sistem DuPont memisahkan kinerja menjadi tiga komponen. Mereka adalah Net Profit Margin (NPM), Return on Assets (ROA) dan Return on Equity (ROE). Objek penelitian ini adalah lima lembaga keuangan terbesar berdasarkan kapitalisasi pasar dan go public. Kelima lembaga keuangan tersebut adalah Bank Republik Indonesia (Persero) Tbk (BBRI), Bank Central Asia Tbk (BBCA), Bank Mandiri (Persero) Tbk (BMRI), Bank Negara Indonesia (Persero) Tbk (BBNI) dan Bank Danamon Indonesia Tbk ( BDMN). Kinerja keuangan lima bank diukur selama tiga periode, dari 2010 hingga 2012. Hanya Bank Negara Indonesia (Persero) Tbk yang memiliki kinerja keuangan terbaik dengan menggunakan Sistem DuPont.

Dapat diketahui beberapa persamaan dan perbedaan dengan penelitian ini yaitu objek penelitian sama-sama meneliti kinerja keuangan pada sektor perbankan syariah dengan menggunakan metode analisis DuPont System. Perbedaan dengan penelitian ini adalah pada objek penelitian terdahulu meneliti 5 bank syariah sedangkan penelitian ini hanya meneliti 1 bank syariah yaitu Bri Syariah, dan perbedaan dari periode yang di teliti yaitu pada penelitian terdahulu 
meneliti pada periode 2010-2012, sedangkan pada penelitian ini meneliti pada periode 2016-2019.

2. Analisis Du Pont Untuk Mengukur Kinerja Keuangan Perusahaan.

Tujuan penelitian ini untuk mengetahui kinerja keuangan PT. Semen Indonesia Tbk dan PT. Indocement Tunggal Prakarsa Tbk dengan menggunakan Du Pont System. Penelitian ini menggunakan jenis data kuantitatif, sedangkan sumber data menggunakan data sekunder dengan teknik pengumpulan data studi pustaka (Library Research). Berdasarkan hasil penelitian disimpulkan bahwa kinerja keuangan pada PT. Semen Indonesia Tbk dan Indocement Tunggal Prakarsa Tbk. Menggunakan Du Pont System menunjukan kinerja keuangan pada PT. Semen Indonesia Tbk selama 6 tahun dari tahun 20122017 diperoleh Return on Equity dengan rata rata $17,01 \%$. Pada PT. Indocement Tunggal Prakarsa Tbk diperoleh rata rata Return on Equity sebesar 18,69\%, dapat dikatakan efisien dalam menggunakan modal. Perusahaan disarankan efisien dalam penggunaan modal dengan meningkatkan penjualan dan mengoptimalkan total aktiva, sehingga mendapatkan tingkat pengembalian Return On Investment yang tinggi dan menambah total aktiva tanpa meningkatkan total ekuitas perusahaan agar menghasilkan Equity Multiplier yang diharapkan dengan begitu Return on Equity akan meningkat (Damayanti, Yudhawati, and Prasetyowati 2019).

Dapat diketahui beberapa persamaan dan perbedaan dengan penelitian ini yaitu samasama meneliti kinerja keuangan dengan menggunakan metode analisis DuPont System. Perbedaan penelitian terdahulu dengan penelitian ini adalah dari objek penelitian, dan periode penelitian, pada penelitian terdahulu tidak meneliti perusahaan sektor perbankan sedangkan pada penelitian ini meneliti pada sektor perbankan, dan pada periode penelitian terdahulu meneliti pada periode 2012-2017, sedangkan pada penelitian ini meneliti pada periode 2016-2019.

3. Analisis DuPont System dalam Mengukur Kinerja Keuangan Perusahaan (Studi Kasus pada Perusahaan Telekomunikasi yang Terdaftar di Bursa Efek Indonesia Periode 2012-2014) (Tarmizi and Marlim 2016).

Tujuan dari penelitian ini adalah untuk menganalisis kinerja keuangan menggunakan analisis DuPont System pada Perusahaan Telekomunikasi yang terdaftar di Bursa Efek Indonesia. Analisis Du Pont System merupakan analisis yang memberikan informasi mengenai faktor-faktor yang menyebabkan naik turunnya kinerja keuangan perusahaan yang menunjukkan hubungan antara Net Profit Margin, Total Assets Turnover dan Return On Investment untuk menentukan Return on Equity perusahaan. Penelitian ini menggunakan penelitian deskriptif. Data yang digunakan adalah data sekunder. Metode pengumpulan data yang digunakan dalam penelitian ini adalah metode dokumentasi atau studi kepustakaan. Teknik analisis yang digunakan adalah analisis deskriptif kualitatif. Berdasarkan hasil penelitian dapat disimpulkan bahwa kinerja keuangan Perusahaan Telekomunikasi yang terdaftar di Bursa Efek Indonesia periode 2012-2014 adalah kinerja keuangan secara umum kurang baik karena secara nilai Return On Investment dan Return on Equity negatif bahkan genap. di bawah standar industri, kecuali PT. Telekomunikasi Indonesia, Tbk kinerja keuangannya cukup baik untuk nilai Return On Investment dan Return on Equity positif, meski di bawah standar industri. Oleh karena itu, perusahaan harus meningkatkan 
kinerja perusahaan, agar dapat mencapai kinerja keuangan perusahaan di atas standar industri.

Dapat diketahui beberapa persamaan dan perbedaan dengan penelitian ini yaitu samasama meneliti kinerja keuangan dengan menggunakan metode analisis DuPont System. Perbedaan penelitian terdahulu dengan penelitian ini adalah dari objek penelitian, dan periode penelitian, pada penelitian terdahulu tidak meneliti perusahaan sektor perbankan sedangkan pada penelitian ini meneliti pada sektor perbankan, dan pada periode penelitian terdahulu meneliti pada periode 2012-2014, sedangkan pada penelitian ini meneliti pada periode 2016-2019.

4. Pengukuran Kinerja Keuangan PT Bank Panin Dubai Syariah Tbk Menggunakan Model Analisis DuPont System (Stiawan and Magfiroh 2021).

Tujuan penelitian ini adalah untuk mengetahui dan membandingkan kinerja keuangan tiap - tiap periode keuangan selama tiga periode dari PT Bank Panin Dubai Syariah Tbk. Periode 2016 - 2018. Kinerja keuangan perusahaan diukur menggunakan Return on Equity (ROE), Return on Investment (ROI), Total Assets Turnover (TAT), dan Net Profit Margin (NPM). Penelitan ini menggunakan metode kuantitatif komparatif dengan menggunakan sumber data sekunder yaitu dokumentasi dari laporan keuangan PT Bank Panin Dubai Syariah Tbk sejak periode 2009. Sampel penelitian terdiri dari 12 laporan keuangan yang dipilih secara purposive sampling dengan jumlah data pengamatan sebanyak 48 data serta teknik analisis data menggunakan Two Ways ANOVA. Hasil analisis menunjukan bahwa terdapat perbedaan yang signifikan kinerja keuangan berdasarkan kategori rasio keuangan selama tiga periode yang diketahui dari nilai signifikan sebesar $0.000<0.05$.

Dapat diketahui beberapa persamaan dan perbedaan dengan penelitian ini menggunakan objek dan metode penelitian yang sama, yaitu objek penelitian pada bank syariah dengan metode DuPon Syatem. Perbedaan dari penelitian terdahulu adalah periode penelitian yang diteliti, pada periode penelitian terdahulu meneliti pada tahun 2016-2018, sedangkan pada penelitian ini meneliti pada periode 2016-2019.

5. Analisis Du Pont System Dengan Time Series Approach (TSA) Dan Cross Sectional Approach (CSA) Dalam Penilaian Kinerja Keuangan Perusahaan (Studi Pada Industri Konstruksi (BUMN) Di Indonesia Yang Listing Di BEI Tahun 2013-2017) (Sunardi 2018).

Penelitian ini bertujuan untuk mengetahu kinerja keuangan perusahaan Industri Konstruksi (BUMN) di Indonesia yang listing di Bursa Efek Indonesia Periode 20132017 dengan pendekatan Du Pont System secara Time Series Approach (TSA) dan Cross Sectional Approach (CSA), Hasil penelitian ini menunjukkan bahwa Perusahaan PT.Adhi Karya (Persero) Tbk. rata-rata $2.789 \%$ lebih basar $2.755 \%$ dikatakan berkinerja Baik, PT. PP (Persero) Periode 2013-2017 dengan nilai rata-rata $2.910 \%$ lebih basar dari rata-rata industri dikatakan berkinerja Baik, PT.Wijaya Karya (Persero) Tbk rata-rata 2.645\% lebih basar dari rata-rata industri dikatakan berkinerja Kurang baik, PT. Waskita Karya (Persero) Tbk rata-rata $2.675 \%$ lebih basar dari ratarata industri sehingga dikatakan berkinerja Kurang baik. menggunakan analisis Return On Investment (ROI) dan Return On Equity (ROE) dengan Time Series Approach (TSA) pada periode 2013 sampai dengan periode 2017 mengalami penurunan dan 
fluktuatif.Analisis Du Pont System secara Cross Sectional Approach (CSA) pada Industri Perusahaan Konstruksi (BUMN) di Indonesia sebesar $2.755 \%$, Hal ini menunjukkan bahwa secara keseluruhan dikatakan berkinerja BAIK.

Dapat diketahui beberapa persamaan dan perbedaan dengan penelitian ini yaitu samasama meneliti kinerja keuangan dengan menggunakan metode analisis DuPont System. Perbedaan penelitian terdahulu dengan penelitian ini adalah dari objek penelitian, dan periode penelitian, pada penelitian terdahulu tidak meneliti perusahaan sektor perbankan sedangkan pada penelitian ini meneliti pada sektor perbankan, dan pada periode penelitian terdahulu meneliti pada periode 2013-2017, sedangkan pada penelitian ini meneliti pada periode 2016-2019.

\section{Kinerja Perusahan Pendekatan Du Pont} System Terhadap Harga Dan Return Saham (Perusahaan yang tergabung dalam Industri Real Estate dan Properti yang terdaftar di Bursa Efek Indonesia Tahun 2011- 2017) (Sunardi 2019).

Tujuan penelitian ini menguji pengaruh secara parsial maupun simultan Harga dan Return Saham. Populasi dan Sampel dalam penelitian ini adalah 19 perusahaan Real estate dan Properti yang terdaftar di BEI pada periode 2011-2017, di Indonsia sesuai dengan kriteria yang ditetapkan Analisis regresi menggunakan analisis data panel. Hasil Penelitian : (1) Variabel Total Aset Turnover (TATO) berpengaruh positif dan signifikan terhadap Harga Saham, (2) Net Profit Margin (MPM) berpengaruh positif dan tidak signifikan terhadap Harga Saham,

(3) Multyplier Equity Ratio (MER) berpengaruh positif dan signifikan terhadap Harga Saham, (4) Return On Equity Du Pond (ROE-DP) berpengaruh negatif dan signifikan terhadap Harga Saham, (5) TATO, MPM, MER, dan ROE-DP secara simultan berpengaruh positif dan signifikan terhadap Harga Saham, (6) Total Aset Turnover (TATO) berpengaruh negatif dan signifikan terhadap Return saham (7) Net Profit Margin (MPM) berpengaruh positif dan tidak signifikan secara parsial terhadap Return saham, (8) Multyplier Equity Ratio (MER) berpengaruh positif dan signifikan terhadap Return saham, (9) Return On Equity Du Pond (ROE-DP) berpengaruh negatif dan signifikan terhadap Return saham, (10) TATO, MPM, MER, ROE-DP secara simultan berpengaruh positif dan tidak signifikan terhadap terhadap Return saham.

Dapat diketahui beberapa persamaan dan perbedaan dengan penelitian ini yaitu samasama meneliti kinerja keuangan dengan menggunakan metode analisis DuPont System. Perbedaan penelitian terdahulu dengan penelitian ini adalah dari objek penelitian, dan periode penelitian, pada penelitian terdahulu tidak meneliti perusahaan sektor perbankan sedangkan pada penelitian ini meneliti pada sektor perbankan, dan pada periode penelitian terdahulu meneliti pada periode 2011-2017, sedangkan pada penelitian ini meneliti pada periode 2016-2019.

7. Analisis Du Pont System Dalam Mengukur Kinerja Keuangan (Studi Empiris Pada PT. Salim Ivomas Pratama Tbk Yang Terdaftar Di BEI) (Dharma 2018).

Tujuan penelitian ini adalah untuk mengetahui kinerja keuangan perusahaan dengan menggunakan Du Pont System yang merupakan pendekatan terpadu analisis rasio keuangan sebagai salah satu alat untuk mengevaluasi laporan keuangan berdasarkan komposisi laporan keuangan di mana pos-pos laporan keuangan diurai secara mendetail. 
Metode Penelitian yang digunakan metode deskriptif, dengan tehnik pengumpulan data dilakukan dengan cara dokumentasi. Berdasarkan hasil analisis data menunjukan kinerja keuangan PT. Salim Ivomas Pratama yang dihitung dengan menggunakan analisis Du Pont System tidak baik, dengan nilai ROA yang mengalami penurunan dari tahun 2012, 2013, dan 2015. Hal ini disebabkan karena penurunan nilai NPM dan TATO karena pada dasarnya nilai ROA dipengaruhi oleh TATO dan NPM. Keadaan ini juga dipengaruhi tingginya penjualan dari pada total aktiva yang dihasilkan oleh perusahaan.

Dapat diketahui beberapa persamaan dan perbedaan dengan penelitian ini yaitu samasama meneliti kinerja keuangan dengan menggunakan metode analisis DuPont System. Perbedaan penelitian terdahulu dengan penelitian ini adalah dari objek penelitian, dan periode penelitian, pada penelitian terdahulu tidak meneliti perusahaan sektor perbankan sedangkan pada penelitian ini meneliti pada sektor perbankan, dan pada periode penelitian terdahulu meneliti pada periode 2012-2015 sedangkan pada penelitian ini meneliti pada periode 2016-2019.

8. Pengaruh Struktur Modal, Ukuran Perusahaan, Pertumbuhan Perusahaan Terhadap Kinerja Keuangan Pada Perusahaan Non Keuangan Dengan Menggunakan Dupont System (Jonathan 2019).

Tujuan Penelitian ini yaitu untuk mengetahui Pengaruh Struktur modal, Ukuran perusahaan, Pertumbuhan perusahaan terhadap Kinerja keuangan dengan menggunakan dupont system. Didalam penelitian ini metode yang digunakan adalah metode kuantitatif menggunakan program Eviews 8. Dari hasil penelitian yang telah dilakukan pada 167 perusahaan non keuangan menunjukan bahwa kinerja keuangan dipengaruhi oleh struktur modal dan ukuran perusahaan. Sedangkan Pertumbuhan perusahaan tidak mempengaruhi Kinerja keuangan. Hasil akhir dari penelitian ini belum memiliki kesimpulan yang kuat bahwa pertumbuhan perusahaan di Indonesia memiliki pengaruh terhadap kinerja perusahaan. R-square yang dihasilkan masih tergolong kecil.

Dapat diketahui beberapa persamaan dan perbedaan dengan penelitian ini yaitu samasama meneliti kinerja keuangan dengan menggunakan metode analisis DuPont System. Perbedaan penelitian terdahulu dengan penelitian ini adalah dari objek penelitian, dan periode penelitian, pada penelitian terdahulu tidak meneliti perusahaan sektor perbankan sedangkan pada penelitian ini meneliti pada sektor perbankan.

9. Analisis Penilaian Kinerja Keuangan Perusahaan Berbasis Du Pont System (Rinawati, Niati, and Suhardjo 2020).

Penelitian bertujuan mengetahui penilaian kinerja keuangan perusahaan untuk saham Jakarta Islamic Index (JII) dan saham Index LQ45 dengan menggunakan Du Pont System dan mengetahui perbedaan kinerja keuangan perusahaan untuk saham Jakarta Islamic Index (JII) dengan Index LQ45. Populasinya adalah saham Jakarta Islamic Index berjumlah 30 emiten dan Index LQ45 berjumlah 45 emiten. Teknik pengambilan sampel menggunakan metode Purposive Sampling. Teknik analisa yang digunakan yakni Du Pount System, uji asumsi klasik, dan Uji Independent Sample t test. Hasil perhitungan analisa Du Pont periode tahun 2014 - 2018 untuk Indeks Saham JII rata-rata ROI berada di bawah rata-rata industri hal ini menunjukkan bahwa kinerja perusahaan dalam menghasilkan laba kurang baik dan rata-rata ROE lebih dari satu hal ini 
menunjukkan semakin efektif dan efisien penggunaan ekuitas perusahaan untuk menghasilkan pendapatan. Hasil perhitungan analisa Du Pont periode tahun 2014 - 2018 untuk Indeks Saham LQ45 diperoleh ratarata $\mathrm{ROI}$ berada di bawah rata-rata industri yang menunjukkan bahwa kinerja perusahaan dalam menghasilkan laba kurang baik, dan rata-rata ROE lebih dari satu hal ini menunjukkan semakin efektif dan efisien penggunaan ekuitas perusahaan untuk menghasilkan pendapatan. Hasil penelitian disimpulkan bahwa terdapat perbedaan yang signifikan antara kinerja keuangan yang diukur dengan ROI untuk jenis saham JII dan LQ45 yang menggambarkan terdapat perbedaan laba bersih yang didapatkan perusahaan dari seluruh kekayaan yang dimilikinya. Sedangkan kinerja keuangan yang diukur dengan ROE untuk jenis saham JII dan LQ45 tidak terdapat perbedaan yang signifikan yang menunjukkan bahwa tidak terdapat perbedaan laba bersih setelah pajak yang dihasilkan perusahaan dan tidak terdapat perbedaan efisiensi penggunaan modal sendiri oleh perusahaan.

Dapat diketahui beberapa persamaan dan perbedaan dengan penelitian ini yaitu samasama meneliti kinerja keuangan dengan menggunakan metode analisis DuPont System. Perbedaan penelitian terdahulu dengan penelitian ini adalah dari objek penelitian, dan periode penelitian, pada penelitian terdahulu tidak meneliti perusahaan sektor perbankan sedangkan pada penelitian ini meneliti pada sektor perbankan, dan pada periode penelitian terdahulu meneliti pada periode 2014-2018, sedangkan pada penelitian ini meneliti pada periode 2016-2019.

\section{METODOLOGI PENELITIAN}

Penelitian ini bertujuan untuk memperoleh gambaran tentang kinerja keuangan perusahaan dengan penerapan metode DuPont System. Disamping itu dengan analisis ini dapat mengevaluasi perubahan-perubahan kondisi dan kinerja perusahaan, apakah ada peningkatan atau penurunan atau keduaduanya. Penelitian ini termasuk kedalam penelitian deskriptif kuantitatif. Dimana jenis data ini adalah data sekunder, merupakan data yang diperoleh dari Laporan keuangan tahunan Bank BRI Syariah, dengan menggunakan perangkat program komputer, yakni melalui program Microsoft Exel. Proses analisis data dalam penelitian ini menggunakan analisis Dupont System.

Dupont System memiliki faktor-faktor yang mempengaruhi besar kecilnya return on investment (ROI) dan hubungannya digambarkan pada bagan sebagai berikut: Bagan 3.1

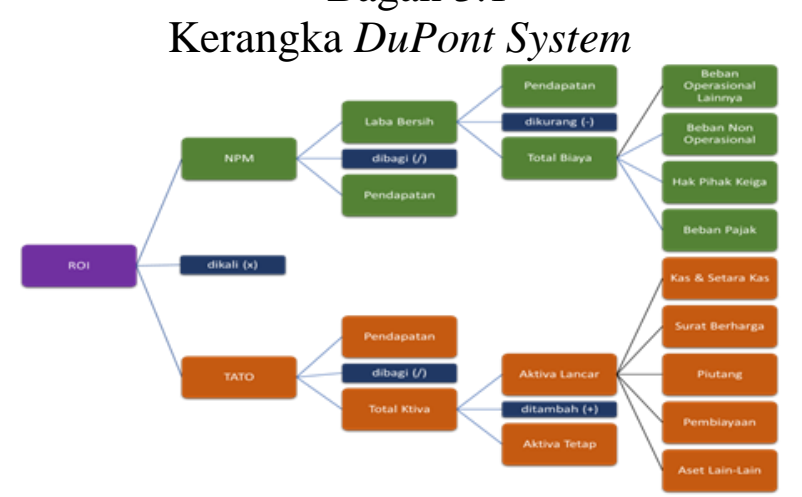

Sumber : Sofyan S. Harhap, Analisis Krisis Atas Laporan Keuangan, 2010.

DuPont Syatem menganggap penting angka Return on Investment (ROI) sehingga analisisnya dimulai dari angka ini. ROI dihitung dari dua komponen

$$
\mathrm{ROI}=\begin{gathered}
\text { Net Profit Margin } \mathrm{x} \text { Total } \\
\text { Assets Trunover }
\end{gathered}
$$

Persentase laba bersih diambil dari Laporan Laba/Rugi sedangkan Aset Turnover diambil dari Neraca. Di sini kelihatan bahwa DuPont System ingin menganalisis laporan keuangan secara integratif (terpadu). Perhitungan kedua komponen adalah sebagai berikut: 
Laba bersih $\times 100 \%$

Pendapatan

Sedangkan laba bersih dihitung dari: Pendapatan - Total Biaya

Total biaya terdiri dari:

Beban Operasional Lainnya Beban +

Non Operasional Beban Pajak + Hak

Pihak Ketiga Atas Bagi Hasil + Beban

Pajak

Aset Turnover dihitung sebagai berikut:

Pendapatan $\times 1$ Kali

Total Aktiva

Total aktiva dihitung dari:

Aktiva Lancar + Aktiva Tetap

Aktiva lancar terdiri dari:

$$
\begin{aligned}
& \text { Kas + Surat Berharga + } \\
& \text { Piutang + Pinjaman Qardh } \\
& + \text { Pembiayaan + Aset } \\
& \text { Lain-Lain }
\end{aligned}
$$

Penguraian komponen laporan keuangan menjadi komponen kecil sampai pada pos-pos individual akan membantu memberikan gambaran lebih lengkap bagi analis.

\section{HASIL DAN PEMBAHASAN A. Hasil Perhitungan Kinerja Keuangan Bank BRI Syariah Dengan DuPont Syatem}

Tabel 4.1

Hasil Perhitungan Net Profit Margin 2016-2019

\begin{tabular}{|c|c|c|c|}
\hline Tahun & Laba Bersih & Pendapatan & NPM \\
\hline 2016 & $170,209,000,000$ & $2,762,168,000,000$ & $6.16 \%$ \\
\hline
\end{tabular}

\begin{tabular}{|l|c|c|c|}
\hline 2017 & $101,091,000,000$ & $2,976,990,000,000$ & $3.40 \%$ \\
\hline 2018 & $106,600,000,000$ & $3,294,489,000,000$ & $3.24 \%$ \\
\hline 2019 & $73,970,000,000$ & $3,625,396,000,000$ & $2.04 \%$ \\
\hline
\end{tabular}

Sumber : Data Diolah Tahun 2020

Berdasarkan hasil perhitungan kinerja keuangan dengan menggunakan metode DuPont System, diketahui bahwa kondisi kinerja keuangan Bank BRI Syariah selama periode 2016-2019 mengalami fluktuasi tiap tahunnya. Net Profit Margin cenderung menurun dan berada dibawah rata-rata pada tahun 2016 sebesar $6.16 \%$ menjadi $3.40 \%$ pada tahun 2017, menurun kembali menjadi $3.24 \%$ pada tahun 2018 , dan pada tahun 2019 mengalami penurunan yang sangat drastis yaitu menjadi $2.04 \%$. Net Profit Margin yang semakin rendah pada tahun 2017, 2018, 2019 disebabkan tingginya hak pihak ketiga atas bagi hasil dan dan tingginya beban usaha sehingga terjadi penurunan terhadap laba bersih yang diperoleh bank. Net Profit Margin terbesar yaitu di tahun 2016 sebesar 6,16\% tetapi pata tahun berikutnya tidak mendapatkan peningkatan melainkan penurunan terhadap laba bersih yang di peroleh bank. Hal ini menunjukan bahwa kemampuan Bank BRI Syariah dalam memperoleh laba bersih dikatakan rendah pada tahun 2017, 2018, dan 2019, dan dikatakan tinggi pada tahun 2016. Selain itu ada beberapa faktor yang mempengaruhi hasil laba menurun yaitu adanya cadangan umum yang mengharuskan perusahaan untuk membuat penyisihan cadangan umm dan wajib sebesar sekurang-kurangnya $20 \%$ dari jumlah modal yang ditempatkan dan disetor penuh. Pada kesepakatan rapat pemegang saham kapitalisasi saldo laba yang di tahan sebesar Rp. 567,382.(BRI Syariah 2020) brDan faktor lain yang mempengaruhi Net Profit Margin mengalami penurunan yang sangat drastis di tahun 2019 yakni kinerja anak usaha di bidang sekuritas yang

EKSISBANK (Ekonomi Syariah dan Bisnis Perbankan), Volume 5, Nomor 2, Desember 2021 
membebani perseroan serta faktor kenaikan beban khususnya beban dana. faktor beban dana akibat dari pengetatan likuiditas secara industri juga menekan pertumbuhan laba perseroan.

Tabel 4.2

Hasil Perhitungan Total Assets Turnover 2016-2019

\begin{tabular}{|l|c|c|c|}
\hline Tahun & Pendapatan & Total Aktiva & TATO \\
\hline 2016 & $2,762,168,000,000$ & $27,687,188,000,000$ & $0.10 \mathrm{Kali}$ \\
\hline 2017 & $2,976,990,000,000$ & $31,543,384,000,000$ & $0.09 \mathrm{Kali}$ \\
\hline 2018 & $3,294,489,000,000$ & $37,869,177,000,000$ & $0.09 \mathrm{Kali}$ \\
\hline 2019 & $3,625,396,000,000$ & $43,062,107,000,000$ & $0.08 \mathrm{Kali}$ \\
\hline
\end{tabular}

Sumber : Data Diolah Tahun 2020

Dari hasil perhitungan Total Assets Turnover mengalami fluktuasi setiap tahunnya dan cenderung mengalami penurunan Total Assets Turnover terbesar yaitu 0,10 kali pada tahun 2016 sedangkan pada tahun 2017 mengalami penurunan sebesar 0,09 kali dan pada tahun 2017 tidak mengalami perubahan yakni masih sebesar 0,09 kali, sedangkan pada tahun 2019 mengalami penurunan sebesar 0,08 kali yang disebabkan meningkatnya pembiayaan. Hal ini menunjukan bahwa kemampuan Bank BRI Syariah dalam menghasilkan pendapatan dan total aktiva dikatakan tinggi pada tahun 2016 dan pada tahun 2017, dan 2018 dikatakan rendah, sedangkan Total Assets Turnover paling rendah terjadi pada tahun 2019. Hal ini menunjukan bahwa kinerja Bank BRI Syariah dalam mengelola Hartanya kurang baik untuk menghasilkan laba operasi.

Tabel 4.3

Hasil Perhitungan Retuen On Invesment 2016-2019

\begin{tabular}{|l|l|l|l|}
\hline Tahun & NPM & TATO & \multicolumn{1}{|c|}{ ROI } \\
\hline 2016 & $6.16 \%$ & 0.10 Kali & $0.61 \%$ \\
\hline 2017 & $3.40 \%$ & 0.09 Kali & $0.32 \%$ \\
\hline 2018 & $3.24 \%$ & 0.09 Kali & $0.28 \%$ \\
\hline 2019 & $2.04 \%$ & 0.08 Kali & $0.17 \%$ \\
\hline
\end{tabular}

Sumber : Data Diolah Tahun 2020

Dari hasil perhitungan Return On Invesment mengalami fluktuasi tiap tahunnya. Pada tahun 2019 sebesar 0,17\%, pada tahun inilah Return On Invesment Bank BRI Syariah paling rendah yang disebabkan rendahnya Net Profit Margin dan Total Assets Turonver. Sedangkan paling tinggi sebesar 0,61\% terjadi pada tahun 2016 dan pada tahun 2017 dan 2018 mengalami penurunan sebesar $0,32 \%$ dan $0,28 \%$ yang disebabkan penurunan $\mathrm{Net}$ Profit Margin dan Total Assets Turnover. Hal ini menunjukan bahwa kinerja Bank BRI Syariah dalam Menghasilkan laba kurag baik pada tahun 2017, 2018, dan 2019. Sedangkan Return On Invesment dikatakan baik pada tahun 2016, meskipun Return On Invesment Mengalami Penurunan namun masih berada di angka positif.

\section{B. Perbandingan Tingkat DuPont Syatem Pada Bank BRI Syariah Periode 2016- 2019}

Tabel 4.4

Perbandingan Tingkat Pada

Bank BRI Syariah 2016-2019

\begin{tabular}{|c|c|c|c|}
\hline Tahun & NPM & TATO & ROI \\
\hline 2016 & $6.16 \%$ & $0.10 \mathrm{Kali}$ & $0.61 \%$ \\
\hline 2017 & $3.40 \%$ & 0.09 Kali & $0.32 \%$ \\
\hline 2018 & $3.24 \%$ & 0.09 Kali & $0.28 \%$ \\
\hline 2019 & $2.04 \%$ & 0.08 Kali & $0.17 \%$ \\
\hline
\end{tabular}


Sumber : Data Diolah Tahun 2020

Dari hasil perhitungan DuPont System mengalami fluktuasi tiap tahunya tingkat DuPont System paling rendah terjadi pada tahun 2019 sebesar $0,17 \%$ yang disebabkan rendahnya Net Profit Margin dan Total Assets Turnover. Pada tahun 2016 DuPont Sytem dikatakan paling tinggi sebesar $0,61 \%$ di tahun ini tingkat DuPont System Bank BRI Syariah dikatakan paling tinggi yang menunjukan bahwa pada saat itu kinerja Bank BRI Syariah dalam pengelolaan hartanya untuk mendapatkan laba usahanya hal ini dikarenakan Net Profit Margin dan Total Assets Turnover memang dikatakan paling tinggi juga, namun cenderung menurun pada tahun 2017,2018, dan 2019 sebesar 0,32\%, 0,28\%, dan 0,17\% disebabkan Net Profit Margin yang cenderung menurun juga, namun pada Total Aset Turnover di tahun 2017 dan 2018 tidak mengalami fluktuasi dikarenakan hasilnya terbilang sama yaitu 0.09 kali. Hal ini menunjukan bahwa kinerja Bank BRI Syariah dalam menghasilkan laba dikatakan kurang baik karena cenderung mengalami penurunan setiap tahunya, meski tingkat DuPont System pada Bank BRI Syariah mengalami fluktuasi, namun masih dikatakan positif dikarenakan pada penetapan kriteria tingkat DuPont Syatem yaitu ROI Bank BRI Syariah masih dikatakan cukup sehat. Sehingga Bank BRI Syariah bisa terus meningkatkan laba bersih dari perputaran aktiva yang dimilikinya.

\section{KESIMPULAN}

Berdasarkan analisis dan pembahasan hasil penelitian dengan perhitungan menggunakan DuPont System pada BRI Syariah periode 2016-2019 dapat diambil kesimpulan bahwa perhitungan kinerja keuangan BRI Syariah periode 2016-2019 dengan menggunakan DuPont System yaitu:
1. Net Profit Margin BRI Syariah mengalami fluktuasi tiap tahunnya. Net Profit Margin paling rendah tejadi pada tahun 2019 yaitu sebesar 2,04\% dan pada tahun 2016 merupakan paling tingginya Net Profit Margin yaitu sebesar $6,16 \%$. Hal ini menunjukkan bahwa BRI Syariah dalam memperoleh laba bersih kurang baik.

2. Total Assets Turnover juga mengalami fluktuasi tiap tahunnya. Total Assets Turnover paling rendah terjadi pada tahun 2019 sebesar 0,08 kali yang disebabkan meningkatnya pembiayaan. Total Assets Turnover paling tinggi terjadi pada tahun 2019 dengan jumlah yang sama yaitu sebesar 0,10 kali.

3. Return On Invesment juga mengalami fluktuatif tiap tahunnya, di mana Return On Invesment paling rendah terjadi pada tahun 2019 sebesar $0,17 \%$ yang disebabkan adanya penurunan nilai Net Profit Margin dan Total Assets Turnover. Pada tahun 2016 Return On Invesment paling tinggi yaitu sebesar $0,61 \%$.

Perbandingan tingkat DuPont System BRI Syariah periode 2016-2019 adalah paling rendah terjadi pada tahun 2019 sebesar $0,17 \%$ yang mengindikasikan bahwa BRI Syariah kurang baik dalam memperoleh laba usaha pada tahun tersebut. Tingkat DuPont System paling tinggi terjadi pada tahun 2016 sebesar $0,61 \%$ yang mengindikasikan bahwa kemampuan BRI Syariah dalam memperoleh laba usaha baik pada tahun tersebut. Hal ini menunjukan bahwa kinerja Bank BRI Syariah dalam menghasilkan laba dikatakan kurang baik karena cenderung mengalami penurunan setiap tahunya, meski tingkat DuPont System pada Bank BRI Syariah mengalami fluktuasi, namun masih dikatakan positif dikarenakan pada penetapan kriteria tingkat DuPont Syatem yaitu ROI Bank BRI Syariah masih 
dikatakan cukup sehat. Sehingga Bank BRI Syariah bisa terus meningkatkan laba bersih dari perputaran aktiva yang dimilikinya..

\section{DAFTAR PUSTAKA}

BRI Syariah. 2020. "Laporan Tahunan." briSyariah.co.id. 2020.

Butar, Melisa Butar. 2019. "Perbandingan Kinerja Keuangan Pada Perum Perumnas Regional I Medan Dan PT Agung Podomoro Land Tbk. Dengan Menggunakan Teknik Analisis Du Pont System." Kumpulan Karya Ilmiah Mahasiswa Fakultas Sosial Sains 1, no. 01 (June).

Damayanti, Lusi, Diah Yudhawati, and Riris Aishah Prasetyowati. 2019. "Analisis Du Pont Untuk Mengukur Kinerja Keuangan Perusahaan." Inovator 8, no. 1 (March): 52-68.

https://doi.org/10.32832/INOVATOR.V 8I1.1842.

Dharma, Moh. Budi. 2018. "Analisis Du Pont System Dalam Mengukur Kinerja Keuangan (Studi Empiris Pada PT. Salim Ivomas Pratama Tbk Yang Terdaftar Di BEI)." LIABILITIES (Jurnal Pendidikan Akuntansi) 1, no. 1 (April): 65-77. https://doi.org/10.30596/liabilities.v1i1. 2032.

Harnita, Aprilia. 2020. "Analisis Sistem Du Pont Untuk Mengukur Kinerja Keuangan Perusahaan Pada PT. Mayora Indah, Tbk Yang Terdaftar Di Bursa Efek Indonesia (BEI).” Kumpulan Karya Ilmiah Mahasiswa Fakultas Sosial Sains 2, no. 02 (June).

Jonathan, Ingrid Brigita. 2019. "Pengaruh Struktur Modal, Ukuran Perusahaan, Pertumbuhan Perusahaan Terhadap Kinerja Keuangan Pada Perusahaan Non Keuangan Dengan Menggunakan
Dupont System." Jurnal Muara Ilmu Ekonomi Dan Bisnis 2, no. 2 (March): 419.

https://doi.org/10.24912/jmieb.v2i2.161 0 .

Kariyoto. 2017. Analisa Laporan Keuangan. Malang: UB Pers.

Lemiyana. 2015. Analisis Laporan Keuangan Basis Komputer. Palembang: noerfikri.

Lesmana, Theresia. 2013. "Penilaian Kinerja Keuangan 5 Perusahaan Perbankan Terbesar Periode 2010-2012 Menggunakan DuPont System." Binus Business Review 4, no. 2 (November): 834-40.

https://doi.org/10.21512/bbr.v4i2.1399.

Moridu, Irwan. 2020. "Analisis Du Pont System Dalam Menilai Kinerja Keuangan Pada CV. Sukses Utama Luwuk Kabupaten Banggai Sulawesi Tengah." Jurnal Ilmiah Manajemen Emor (Ekonomi Manajemen Orientasi Riset) 4, no. 1: 41-52.

Munawir. 2016. Analisis Laporan Keuanga. Yogyakarta: Liberty.

Rahayu, Widya. 2021. "Analisis Perbandingan Kinerja Keuangan Antara PT. Bank Syariah Mandiri Dengan PT. Bank Rakyat Indonesia Syariah Ditinjau Dari Maqasid Syariah: Pendekatan Syariah Maqasid Index (SMI) Tahun 2017." Kumpulan Karya Ilmiah Mahasiswa Fakultas Sosial Sains 1, no. 01 (June).

Rinawati, Tri, Asih Niati, and Yohanes Suhardjo. 2020. "Analisis Penilaian Kinerja Keuangan Perusahaan Berbasis Du Pont System.” Jurnal Dinamika Sosial Budaya 22, no. 2: 174. https://doi.org/10.26623/jdsb.v22i2.2794.

Stiawan, Evan, and Vivi Esty Magfiroh. 2021. 
"Pengukuran Kinerja Keuangan PT Bank Panin Dubai Syariah Tbk Menggunakan Model Analisis DuPont System." Telaah Bisnis 21, no. 1 (April): 47. https://doi.org/10.35917/tb.v21i1.212.

Sunardi, Nardi. 2018. "Analisis Du Pont System Dengan Time Series Approach (Tsa) Dan Cross Sectional Approach (Csa) Dalam Penilaian Kinerja Keuangan Perusahaan (Studi Pada Industri Konstruksi (BUMN) Di Indonesia Yang Listing Di BEI Tahun 2013-2017)." Jurnal SEKURITAS (Saham, Ekonomi, Keuangan Dan Investasi) 1, no. 4 (June). https://doi.org/10.32493/skt.v1i4.1375.

- 2019. "Kinerja Perusahan Pendekatan Du Pont System Terhadap Harga Dan Return Saham (Perusahaan Yang Tergabung Dalam Industri Real Estate Dan Properti Yang Terdaftar Di Bursa Efek Indonesia Tahun 20112017)." JIMF (Jurnal Ilmiah Manajemen Forkamma) 1, no. 3 (April). https://doi.org/10.32493/frkm.v1i3.2546.

Suwiknyo, Dwi. 2019. Analisis Laporan Keuangan Perbankan Syariah. Yogyakarta: Pustaka Pelajar.

Syamsul, Herawati. 2017. "Penerapan Kepemimpinan Kepala Sekolah Dalam Meningkatkan Kinerja Guru Pada Jenjang Sekolah Menengah Pertama (SMP)." Idaarah: Jurnal Manajemen Pendidikan 1, no. 2 (December). https://doi.org/10.24252/IDAARAH.V1I 2.4271 .

Tarmizi, Rosmiati, and Merlinda Marlim. 2016. "Analisis Du Pont System Dalam Mengukur Kinerja Keuangan Perusahaan (Studi Kasus Pada Perusahaan Telekomunikasi Yang Terdaftar Di Bursa Efek Indonesia Periode 2012-2014)." Jurnal Akuntansi Dan Keuangan 7, no. 2
(September).

https://doi.org/10.36448/JAK.V7I2.756.

Warsono. 2016. Manajemen Keuangan Perusahaan. Jakarta: Buyu Media.

Wilmar Amonio Gulo, dan Wita Juwita Ermawat. 2011. "Analisis Economic Value Added (EVA) Dan Market Value Added (MVA) Sebagai Alat Pengukur Kinerja Keuangan PT SA,." Jurnal Manajemen Dan Organisas 2, no. 2: 2.

EKSISBANK (Ekonomi Syariah dan Bisnis Perbankan), Volume 5, Nomor 2, Desember 2021 